\title{
Photoreactions of 4,4'-Bis(pentamethyldisilanyl)biphenyl
}

\author{
Seung Ki Park \\ Department of Chemistry, College of Katural Sciences. The Univensitv of Sum on, Suw $145-743, \mathrm{Korea}$ \\ E-mail: skparkiásuwonackr \\ Received March 23, 2007
}

Key Words : 4.4'-Bis(pentamethỵldisilanỵl)biphenỵl. Silene

It is well known that the photolysis of aryldisilanes ${ }^{l}$ gave the silenes containing $\mathrm{Si}=\mathrm{C}$ bond as reaction intermediates since the earliest report on the photolysis of phenylpentamethỵldisilane and ( $p$-tolyl)pentamethyldisilane by Ishikawa ef $a^{2}$ in 1975 . The silenes arising from the 1.3trimethylsilyl radical shift of a teminal silyl group in the disilane moiety onto an ortho carbon atom in the aryl ring upon irradiation react with various substrates to give the various photoproducts. ${ }^{3-25}$ In connection with the reactions of silene intermediates in the absence of trapping agents. Ishikawa and co-workers ${ }^{26.27}$ reported that the photolysis of 1.4-bis(pentamethyldisilanyl)benzene in hexane gave two isomeric dimers 7.7.8.8-tetramethyl-3.12-bis(pentamethyldisilanỵl)-13.14-bis(trimethỵlsilyl)-7.8-disilatricyclo[7.3.1.1 tetradeca-3.5.9.11-tetraene and 7.7.8.8-tetramethyy-3.12bis(pentamethyldisilanyl)-10.14-bis(trimethylsilyl)-7.8-disilatricyclo[7.3.1.1.6. $]$ tetradeca-3.5.9(13).11-tetraene. in a ratio of $1: 1$ through head-to-head dimerization of silene intermediate. Very recently. I reported that the photoreaction of (2-hydroxymethylphenyl)pentamethyldisilane in methanol provides a novel intramolecular photoproduct via silene intermediate arising from 1.3-migration of trimethylsilỵl radical. which is fonmed via homolytic cleavage of siliconsilicon $\sigma$ bond in the disilane moiety upon irradiation to the $\mathrm{C}_{6}$ position of benzene ring. ${ }^{2}$ In connection with my continuous studies for the utility of silacyclopropenes. $9-4 ?$ silaallenes. and silenes ${ }^{44}$ as reaction intenmediates in organic synthesis of silicon-containing heterocyclic compounds. the present author has now investigated the photochemistry of 4.4'-bis(pentamethỵldisilanỵl)biphenyl 1 expecting the formation of two silene intermediates in one molecule. In this paper. I would like to report the detailed photochemical study of 4.4'-bis(pentamethyldisilanyl)biphenyl.

The starting 4.4'-bis(pentamethyldisilanyl)biphenyl 1 was prepared by the reaction of 4.4 -diiodobiphenyl with chloropentamethyldisilane in $80 \%$ yield (Scheme 1).

In order to investigate whether or not the photolysis of 1 affords two silene intermediates and the photoproducts from
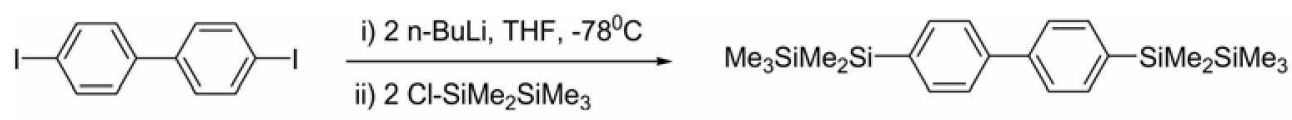

$1,80 \%$

Scheme 1

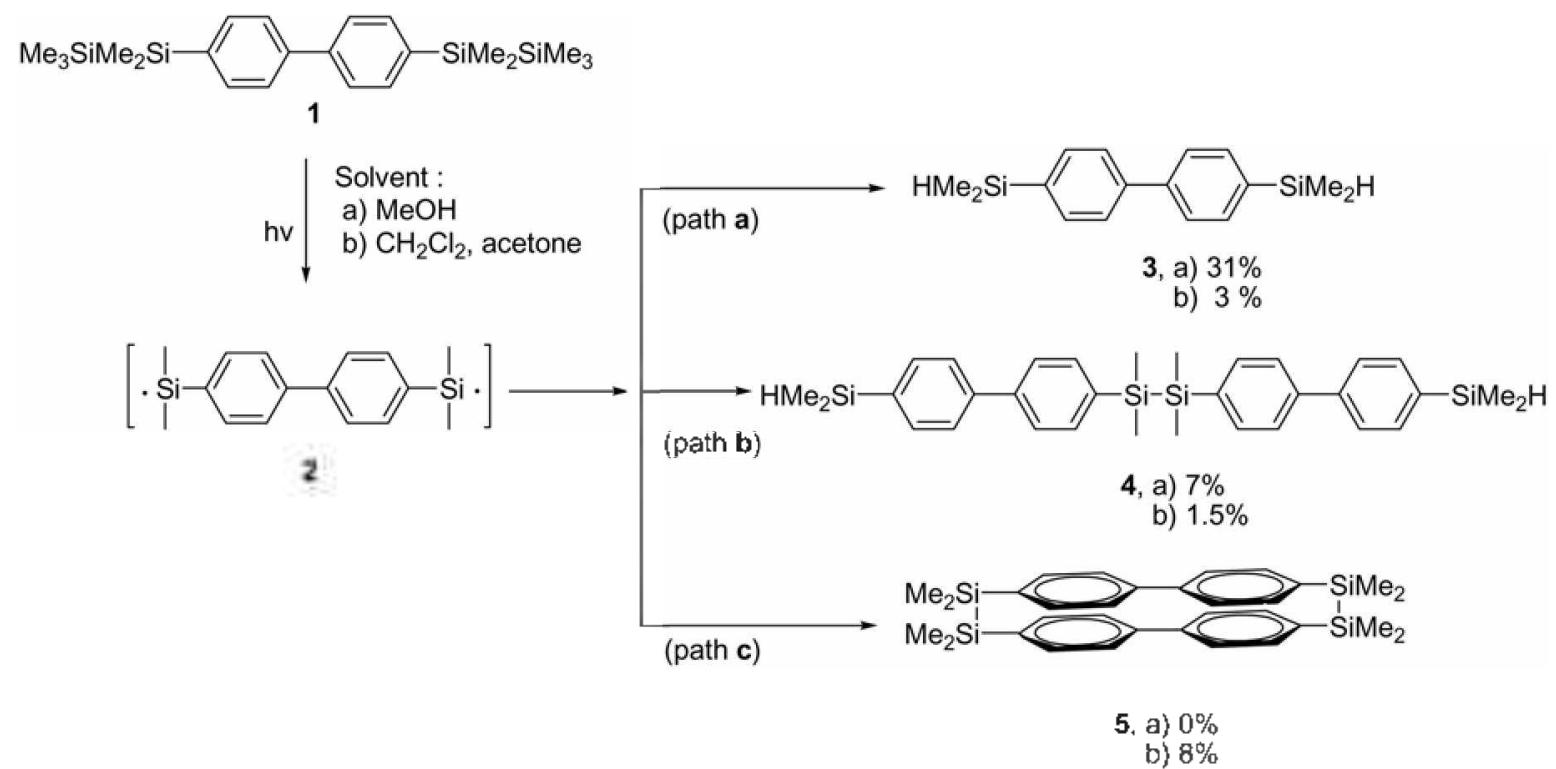

Scheme 2 
the reaction of the silene moiety thus formed with the trapping agent, methanol, the photolysis of $\mathbf{1}$ in the presence of methanol was performed.

Irradiation of 1 in deaerated methanol with $254 \mathrm{~nm}$ UV light afforded two photoproducts 3 and $\mathbf{4}(31$ and $7 \%$ yield. respectively) along with some decomposition products of unknown structure as shown in Scheme 2, when $92 \%$ of 1 was photolyzed but the expected photoproducts from the reaction of the silene intermediate with methanol were not obtained, indicating that the photolysis of $\mathbf{1}$ did not give the silene intermediate in marked contrast to the photolysis of 1,4-bis(pentamethyldisilanyl)benzene ${ }^{26.27}$ which produces the two dimeric photoproducts via the silene intermediates. In comnection with the formation of the conpounds having the dimethylsilane moiety like 3 or 4 , Sakurai et al ${ }^{45}$ reported that the photolysis of 4-(trifluoromethyl)phenylpentamethyldisilane in ethanol-hexane mixture affords 4-(trifluoromethyl)pheny ldimethylsilane. (trimethylsilyl)[(ethoxydimethyl)silyl](trifluoromethyl)cyclohexadienes. and 4(trifluoromethyl)phenyl(ethoxydimethyl)silane in 24. 41. and $15 \%$ yields. respectively. In this reaction, it was concluded that 4 -(trifluoromethyl)phenyldimethylsilane was formed through the nucleophilic attack of ethanol at the $\beta$ silicon atom of the disilane moiety. In the photoly sis of 1 . the formation of 3 can be also explained by the nucleophilic attack of two methanol molecules at the two disilane moieties of 1 but the formation of $t$ can not be explained because the silicon-silicon bond in $\mathbf{4}$ must be formed. Therefore, the existence of diradical species 2 as reaction intermediate was proposed in the photolysis of 1 . The formation of a photoproduct 3 may be understood in terms of the homolytic cleavage of two silicon-silicon $\sigma$ bonds in the photoexcited state of $\mathbf{1}$ and then the hydrogen abstraction by the diradical species 2 thus formed in methanol solvent at both sides. The production of the photoproduct + was most likely explained by a mechanism involving the silyl radicalsilyl radical coupling reaction of $\mathbf{2}$ at one side, followed by the hydrogen abstraction by the remaining radical part in methanol solvent.

The structures of the photoproducts 3 and $\mathbf{4}$ were determined by various physical methods. such as ${ }^{1} \mathrm{H}$ NMR, ${ }^{13} \mathrm{C}$ NMR. UV. FT-IR, and high resolution mass spectrometry. The ${ }^{1} \mathrm{H}$ NMR spectra of $\mathbf{3}$ and $\boldsymbol{4}$ show septet resonances at $\delta$ 4.48 and $4.50 \mathrm{ppm}$, respectively, due to a Si-H proton of dimethylsilyl group. The ${ }^{13} \mathrm{C}$ NMR spectrum of 3 reveals resonances due to four kinds of aromatic carbons at 126.8 . 134.8. 136.7 and $142.1 \mathrm{ppm}$. dimethylsily' carbon at -3.52 $\mathrm{ppm}$ and that of $\mathbf{4}$ shows resonances due to eight kinds of aromatic carbons at $126.7,126.9,133.8,134.8,136.6,138.9$. 142.1 , and $142.2 \mathrm{ppm}$. two kinds of dimethylsilyl carbon at -3.48 and $1.2 \mathrm{ppm}$. The IR absorption spectra of 3 and 4 show characteristic absorptions at 2118.5 and $2117.8 \mathrm{~cm}^{-1}$. respectively. due to the $\mathrm{Si}-\mathrm{H}$ stretching mode in the dimethylsilyl group. The mass spectra of $\mathbf{3}$ and $\mathbf{4}$ show parent ions at $m \geq 270$ and 538. respectively. These results are wholly consistent with the structures proposed for $\mathbf{3}$ and $\mathbf{4}$

In order to investigate the reactivity' of acetone instead of methanol as a trapping agent. the photolysis of 1 in the presence of acetone was carried out. Irradiation of 1 in a deaerated methylene chloride in the presence of acetone with $254 \mathrm{~nm}$ UV light afforded three compounds 3 (3\% yield). $\mathbf{4}$ ( $1.5 \%$ yield). and 5 ( $8 \%$ yield) along with some decomposition products of unknown structure as shown in Scheme 2 , when $88 \%$ of 1 was photolyzed but the expected photoproducts from the reaction of the photoexcited state of 1 with acetone were not obtained. In this reaction, the evidence for the formation of silene intermediate was not also detected. The formation of $\mathbf{3}$ and $\mathbf{4}$ can be also explained by the hydrogen abstraction by the diradical species 2 in the solvent cage the same as in methanol solvent. The formation of a novel photodimer $\mathbf{5}$ can be rationalized in terms of the initial formation of diradical species 2 upon irradiation, followed by the silyl radical-silyl radical coupling reactions of $\mathbf{2}$ in two sites to give the dimer of $\mathbf{2}$. The photoproduct 5 was obtained only in a deaerated methylene chloride in the presence of acetone as solvent. indicating that diradical species 2 probably has the longer lifetime in the absence of silyl radical trapping agents than in methanol. The compound $\mathbf{5}$ was not obtained in the presence of silyl radical trapping agent, methanol. because 2 readily reacts with methanol to give the photoproducts 3 and $\mathbf{4}$.

The photoreaction of 1 in a deaerated hexane with $254 \mathrm{~nm}$ UV light did not give any photoproduct in contrast to the photoreaction of 1 in the presence of methanol or acetone as solvent.

The structure of the photoproduct $\mathbf{5}$ was determined by various plyysical methods. such as ${ }^{1} \mathrm{H}$ NMR. ${ }^{13} \mathrm{C}$ NMR. UV, FT-IR, and high resolution mass spectrometry. The ${ }^{1} \mathrm{H}$ NMR spectrum of 5 shows aromatic $\mathrm{AB}$ quartet at $\delta 7.06$ and 7.17 ppm, due to para-disubstituted aromatic protons. The ${ }^{13} \mathrm{C}$ NMR spectrum of $\mathbf{5}$ reveals resonances due to four kinds of aromatic carbons at $125.9,133.5 .136 .9$. and $141.6 \mathrm{ppm}$. dimethylsilyl carbon at $-0.069 \mathrm{ppm}$. The mass spectrum of 5 shows a parent ion at $m z 536$, indicating that a compound 5 is the dimer of diradical species 2 . These results are wholly consistent with the structure proposed for 5 .

In conclusion, the photoly'sis of $\mathbf{1}$ in methanol provided 3 and $\mathbf{4}$ via diradical species 2 but the expected photoproducts from the reaction of the silene intermediate with methanol were not obtained. The photolysis of 1 in a deaerated methylene chloride in the presence of acetone provided a novel photoproduct 5 in addition to 3 and 4 via diradical species 2 but the expected photoproducts from the silene intermediate were also not obtained in this photoreaction.

\section{Experimental}

Synthesis of 4,4'-bis(pentamethyldisilanyl)biphenyl 1. A solution of 4.4'-diiodobiphenyl (1.0 g. $2.46 \mathrm{mmol})$ in THF $(20 \mathrm{~mL})$ was treated with $n$-BuLi $(2.07 \mathrm{~mL} .5 .17 \mathrm{mmol})$ at $-78^{\circ} \mathrm{C}$ followed by chloropentametlyyldisilane $(1 \mathrm{~mL} .5 .17$ mmol). The reaction mixture was warmed to room temperature and stirred for 5 hrs. After evaporation of solvent. the reaction mixture was extracted with ethyl acetate $(3 \times 20$ 
$\mathrm{mL})$, washed with water $(3 \times 20 \mathrm{~mL})$, and dried with $\mathrm{MgSO}_{4}$. and concentrated in vacto to give the crude product. Flash column chromatography using $n$-hexane:ethyl acetate (100:1, $v / v)$ as an eluent gave $1\left(0.82\right.$ g. $80 \%$ yield); m.p. $35.36^{\circ} \mathrm{C}$. ${ }^{1} \mathrm{H} \mathrm{NMR}\left(\mathrm{CDCl}_{3} .300 \mathrm{MHz}\right) \delta_{\mathrm{H}} 0.10(18 \mathrm{H}, \mathrm{s}), 0.38(12 \mathrm{H} . \mathrm{s})$. $7.54(4 \mathrm{H}$, d. $J=4.8 \mathrm{~Hz}$. A part of AA'BB' spectrum). 7.60 $\left(4 \mathrm{H}, \mathrm{d}, J=4.8 \mathrm{~Hz}, \mathrm{~B}\right.$ part of AA'BB' spectrum): ${ }^{13} \mathrm{C}$ NMR $\left(\mathrm{CDCl}_{3}, 75 \mathrm{MHz}\right) \delta--3.74,-2.00,126.6 .134 .5 .138 .7$. 141.2; UV ( $\left.\mathrm{CH}_{2} \mathrm{Cl}_{2}\right) \lambda_{\max } 279 \mathrm{~nm}$ : FT-IR (NaCl) 3065.3. 2951.5. 2893.6, 1594.2, 1485.6. 1245.7. 1109.6. 832.5. $796.3 \mathrm{~cm}^{-1}$ : MS $(70 \mathrm{eV}) m z 414\left(\mathrm{M}^{-}\right)$: MS $m z(\%) 414\left(\mathrm{M}^{+}\right.$. 26). 341 (100), 283 (79), 267 (13), 253 (14), 224 (9). 131 (17), 116 (35); HRMS ( $\left.\mathrm{M}^{-}\right)$calcd for $\mathrm{C}_{22} \mathrm{H}_{38} \mathrm{Si}_{4} 414.205 \mathrm{l}$. found +14.2079 .

Irradiation of 4,4 '-bis(pentamethyldisilanyl)biphenyl 1 in methanol. A solution $\left(3 \times 10^{-2} \mathrm{M}\right)$ of $4,4^{\prime}$-bis(pentamethyldisilanyl)biphenyl $1(0.5 \mathrm{~g})$ in methanol $(40 \mathrm{~mL})$ was deaerated by nitrogen purging for $30 \mathrm{~min}$ and irradiated in a Rayonet photochemical reactor, model RPR-208, equipped with RUL $254 \mathrm{~nm}$ lamps. After irradiation for $38 \mathrm{~h}$. the resulting photoreaction mixture was concentrated in vacto. The photoproducts 3 and 4 were isolated in $101 \mathrm{mg}$ ( $31 \%$ yield) and $45.5 \mathrm{mg}$ ( $7 \%$ yield). respectively. in addition to $8 \%$ (40 mg) of the starting compound 1 by column chromatography with $n$-hexane/ethyl acetate $(100 / 1, v / v)$ as an eluent followed by normal phase HPLC using $n$-hexane/ ethyl acetate (40/L. v/v) as an eluent.

3: ${ }^{1} \mathrm{H}$ NMR $\left(\mathrm{CDCl}_{3}, 300 \mathrm{MHz}\right) \delta_{\mathrm{H}} 0.39(12 \mathrm{H}$. d. $J=3.9$ $\mathrm{Hz}), 4.48(2 \mathrm{H}$. septet. $J=3.9 \mathrm{~Hz}) .7 .60-7.64(8 \mathrm{H} . \mathrm{ml}):{ }^{13} \mathrm{C}$ NMR $\left(\mathrm{CDCl}_{3} .75 \mathrm{MHz}\right) \delta,-3.52,126.8 .134 .8 .136 .7$. 142.1; UV $\left(\mathrm{CH}_{2} \mathrm{Cl}_{2}\right) \lambda_{\max } 265 \mathrm{~nm} ; \mathrm{FT}-\mathrm{IR}(\mathrm{NaCl}) 3065.7$. $2957.3,2924.9 .2118 .5$. 1594.9, 1381.2, 1249.3. 1117.0. 877.5. $807.7 \mathrm{~cm}^{-1}$ : MS (70eV) $m z 270\left(\mathrm{M}^{-}\right)$: MS $m z(\%)$ $270\left(\mathrm{M}^{-} .7\right), 269$ (27). $213(16), 212(100) .166(8) .75(9)$ : HRMS $\left(\mathrm{M}^{-}\right)$calcd for $\mathrm{C}_{16} \mathrm{H}_{22} \mathrm{Si}=270.1260$. found 270.1221 .

4: m.p. $54-56{ }^{\circ} \mathrm{C},{ }^{1} \mathrm{H}$ NMR $\left(\mathrm{CDCl}_{3}, 300 \mathrm{MHz}\right) \delta_{\mathrm{H}} 0.40$ (12H. d. $J=3.6 \mathrm{~Hz}$ ). $0.41(\mathrm{I} 2 \mathrm{H}, \mathrm{s}) .4 .50$ (2H. septet, $J=3.6$ $\mathrm{Hz}), 7.61-7.65(16 \mathrm{H}, \mathrm{m}):{ }^{13} \mathrm{C} \mathrm{NMR}\left(\mathrm{CDCl}_{3}, 75 \mathrm{MHz}\right) \delta$. -3.48. 1.20. 126.7, 126.9. 133.8. 134.8. 136.6. 138.9, 142.1. 142.2: UV $\left(\mathrm{CH}_{2} \mathrm{Cl}_{2}\right) \lambda_{\max } 264 \mathrm{~mm}$; FT-IR $(\mathrm{NaCl}) 3065.8$. 2957.6. 2117.8. 1595.8. 1381.1. 1253.3. 1118.9. 1061.9. $880.5 .831 .7 .789 .0 \mathrm{~cm}^{-1}: \mathrm{MS}(70 \mathrm{eV}) m z 538\left(\mathrm{M}^{+}\right)$; MS $m: z$ (\%) $538\left(\mathrm{M}^{-}, 4\right), 346(10) .328(100) .270(70) .211(9), 195$ (30): HRMS $\left(\mathrm{M}^{-}\right)$calcd for $\mathrm{C}_{32} \mathrm{H}_{4} \mathrm{Si}_{4}$ 538.2364. found 538.2327

Irradiation of 4,4'-bis(pentamethyldisilanyl)biphenyl 1 in methylene chloride in the presence of acetone. $A$ solution $\left(3 \times 10^{-2} \mathrm{M}\right)$ of $4,4^{\prime}$-bis(pentamethy ldisilanyl)biphenyl $1(0.5 \mathrm{~g})$ and acetone $(4 \mathrm{~mL})$ in methylene chloride $(40 \mathrm{~mL}$ ) was deaerated by nitrogen purging for $30 \mathrm{minn}$. and irradiated in a Ray'onet photochemical reactor. model RPR208. equipped with RUL $254 \mathrm{~nm}$ lamps. After irradiation for $38 \mathrm{~h}$. the resulting photoreaction mixture was concentrated in vacuo. The photoproducts 3,4 . and 5 were isolated in $(9.8$ $\mathrm{mg} .3 \%$ yield). ( $9.7 \mathrm{mg} .1 .5 \%$ yield), and ( $51.8 \mathrm{mg} .8 \%$ yield). respectively. in addition to $12 \%(60 \mathrm{mg})$ of the starting material 1 by column chromatography with $n$-hexane/ethyl acetate $(100 / 1 . \mathrm{v} / \mathrm{v})$ as an eluent followed by normal phase HPLC using $n$-hexane/ethyl acetate $(40 / 1 . v / v)$ as an eluent.

5: m.p. $165.167^{\circ} \mathrm{C}$ (decomposed). ${ }^{1} \mathrm{H}$ NMR ( $\mathrm{CDCl}_{3} .300$ $\mathrm{MHz}) \delta_{\mathrm{H}} 0.43(24 \mathrm{H}, \mathrm{s}), 7.06(8 \mathrm{H} . \mathrm{d}, J=7.8 \mathrm{~Hz}$, A part of AA'BB' spectrum). $7.17(8 \mathrm{H}, \mathrm{d}, J=7.8 \mathrm{~Hz}$. B part of AA'BB' spectrum): ${ }^{12} \mathrm{C}$ NMR $\left(\mathrm{CDCl}_{3} .75 \mathrm{MHz}\right) \delta_{c}-0.069$, 125.9, 133.5. 136.9. 141.6: UV $\left(\mathrm{CH}_{2} \mathrm{Cl}_{2}\right) \lambda_{\text {max }} 260 \mathrm{um}: \mathrm{FT}-$ IR $(\mathrm{NaCl}) 3059.0,2960.0 .2917 .0,2849.1,1559.0 .1379 .7$. $1275.2,1260.9,1046.4,792.9 .764 .2,750.0 \mathrm{~cm}^{-1}$ : MS (70 eV) $m z 536\left(\mathrm{M}^{+}\right)$; MS $m z(\%) 536\left(\mathrm{M}^{-}, 0.6\right) .342(13), 328$ (100), $270(76) .212(8), 196(34) .149(5)$ : HRMS (M-) calcd for $\mathrm{C}_{32} \mathrm{H}_{410} \mathrm{Si}_{4} 536.2207$, found 536.2272 .

Acknowledgements. The author would like to thank Miss $\mathrm{Su}$ Yeon Gong at the university of Suwon for helping the preparation of compounds.

\section{References}

1. (a) Patai, S.: Rappoport, Z. The Chemistry of Organic Silicon Compounds: Wiley: New York. 1989. (b) Rappoport. Z: Apeloig. Y. The Chemistry of Onganic Silicon Componds. Wiley: New York. 1998: vol. 2. (c) Rappoport. Z: Apeloig. Y. The Chemistry of Organic Silican Componds. Wiley: New York. 2001: vol. 3. (d) Brook, M. A. Silicon in Organic. Onganometallic, and Polumeric Chemistry, Wiley: New York. 2000.

2. Ishikawa, M.: Fuchikami. T.; Sugaya T.; Kumada M. $J$. Am. Chent Soc. 1975. 97.5923

3. Ishikawa. M.: Fuchikami. I.: Kumada. M. J. Orgunontet. Chent. 1976. 118.155

4. Morkin, T. L.; Leigh, W. J. Acc. Chem Res. $\mathbf{2 0 0 1}, 34.129$

5. Leigh. W. J.: Sluggett. G. W. J. Am. Chem. Soc. 1994, 116. 10468.

6. Steinmetz, M. G. Chem. Rev $1995,95,1527$.

7. Nate. K.: Ishikawa. M.: Ni. H.: Watanabe. H.: Saheki. Y. Orgononetallics 1987.6 .1673 .

8. Ohshita. T.: Ohsaki. H.: Ishikawa. M.: Tachibana. A.: Kurosaki. Y: Yamabe, T: Minato, A. Organometallics 1991. 10. 880.

9. Takaki, K; Sakamoto, H; Nishimura. Y.: Sugihara, Y, Ishikawa. M. Organonetallics 1991. 10,888.

10. Ohshita. T.: Onsaki. H.: Ishikawa. M.: Tachibana. A.: Kurosaki. Y: Yamabe. T.: Tsukihara. T.: Takahashi. K.: Kiso. Y. Orgonontetallics 1991. 10.2685

11. Ishikawa, M: Nishimura, Y.: Sakamoto, H. Organonetallics 1991. 10,2701

12. Ishikawa, M; Fuchikami. T; Kumada, M. J. Organonet. Chem. 1977. 133.19

13. Ohshita. J.: Niwa. H.: Ishikawa. M. Ongenonetallics 1996. 15. 4632.

14. Toltl, N. P. Leigh, W. J. Onganometallics 1996. 15.2554.

15. Leigh. W. J.: Sluggett. G. W. Organonetallics 1994, 13, 269.

16. Ishikawa, M.; Fuchikami. T:; Kumada. M. J. Organomet. Chem. 1976. 118. 139

17. Ishikawa. M.: Fuchikami. T.: Kumada. M. J. Orgmontet. Chent. 1978. 162.223

18. Ishikawa, M.: Sakamoto, H.: Kanetani, F.: Minato. A. Organometallics $1989.8,2767$

19. Sakurai, H. J. Organonet. Chem 1980, 200, 261.

20. Guseltikor. L. E.: Nametkin. N. S. Chent Re?: 1979. 79.529

21. Ohshita. . .: Niwa. H.: Ishikawa. M.: Yamabe. T.: Yoshii. T.: Nakamura. K. J.Ant. Chent. Soc. 1996. 118.6853.

22. Ishikawa, M.: Oda M: Miyoshi, N.: Fabry, L.: Kumada. M. Yamabe. T; Akagi, K.; Fukui, K. J. Am. Chem. Soc, 1979, 101. 4612.

23. Ohshita. J.: Ohsaki. H.: Ishikawa. M. Organonetallics 1991. 10. 
2695

24. Sakurai. H.: Nakadaira. Y: Kira. M.: Sugivama. H.: Yoshida. K.: Takiguchi. T.J. Organontet Chem 1980. 184. C 36.

25. Ishikawa. M.: Fuchikami, T.: Kumnada. M. J. Organomet. Chem. $1977,127,261$

26. Ishikawa. M.: Kikuchi. M.: Kunai. A.: Takeuchi, T.: Tsukihara, T. Kido. M. Organometallics 1993. I2.3474.

27. Ishikawa. M.: Kikuchi. M.: Watanabe. K.: Sakamoto. H.: Kunai. A. J. Organomet Chem. 1993. H3. C3.

28. Park; S. K. Bull. Konean (Chem. Soc. 2006, 27. 1305.

29. Shim, S. C.: Park, S. K. Tetratredron Lett. 1998. 39.6891

30. Shim, S. C. Park, S. K. Bull Korean them. Soc, 1998, 19,686.

31. Shim. S. C.: Park. S. K. Bull. Korean Chent Soc. 1999. 20. 547.

32. Park. S. K.: Shim. S. C.: Seo. Y. W.: Shin. J. H. Tetrahedron Lett. 1999, 40,4575

33. Park, S. K. Seo, K. H.: Shim. S. C. J. Photochem. Photobiol. A: Chem. $1999,127.67$
34. Shim. S. C.: Park. S. K. J. Photosci. 1999. 6. 13.

35. Park. S. K.: Shim. S. C. J. Photachem. Photobiol. A: Chem. 2000. 136. 219.

36. Park. S. K. J. Photochem. Photobiol A: Chem 2000. $135,155$.

37. Park. S. K. J. Photochem Photobiol. A: Chem 2001. 1H, 167.

38. Park. S. K. Bull. Korean Chem. Soc. 2001. 22, 12012

39. Park. S. K. J. Photosci. 2002. 9. 1.

40. Park. S. K.: Baek. D. I. J. Photochem. Photobiol A: Chent 2002. 150. 125.

41. Park. S. K.; Baek. D. J. J. Photochem. Photobiol A: Chem 2003. 154. 145 .

42. Park. S. K.; Baek. D. J. J. Photochem. Photobiol A: Chem 2003. 157.15.

43. Park. S. K.: Baek. D. T. J. Photochem. Photobiol A: Chent 2004. 163.87.

44. Park. S. K. J. Photochem. Photobiol A: Chem 2005. 173, 29.

45. Kira. M.: Mivazawa, T.: Sugivama, H.: Yamaguchi, M.: Sakurai. H. d. Am. Chem. Soc. 1993. 115.3116. 